\title{
メチルメタクリレートの塊状重合体およひ乳化重合体の 立体特異性の重合率および重合温度依存性
}

(昭 和 35 年 10 月 22 日 受 理)

$$
\text { 渡辺治 昭* }
$$

メチルメタクリレートの塊状重合体，乳化重合体の立体規則性を赤外線スペクトルによって求め次の結果を得た。

(1) 重合体の $S \%, D \%, I \%$ の間には Bovey, Tiers が指摘しているよ5に次の関係式が成立する。

$$
S / 100=\beta^{2}, \quad I / 100=(1-\beta)^{2}, \quad D / 100=2 \beta(1-\beta)
$$

（2）重合率により立体規則性は塊状重合の場合には峦化するが乳化重合の場合には変化しない。

（3）重合温度により乳化重合の場合も塊状重合の場合も立体規則性は温度が上年するとS\%が減少する方向に变化 する。

（4）単量体が syndiotactic と isotactic 飞付加する活性化ェネルギーの差は塊状重合の場合は $1.38 \mathrm{kcal}$, 乳化重合 の場合は $1.44 \mathrm{kcal}$ であった。

（5）塊状重合と乳化重合火彷ける $S \%$ と $1 / T$ との関係式を誘導し，これに基いて，重合温度と $S \% ， D \% ， I \%$ と の関係をそれぞれ図示した。塊状重合と乳化重合においては同じ温度でははとんど同じ S\%，I\% よ。び D\%の重合体 となる。

\section{1 緒言}

ラジカル触媒による塩化ビニル1)，酢酸ビニル2)，メチルメタ クリレートง（以下 MMA と記す）の重合体の立体規則性は, X線回折扣よび赤外線スペクトル等の手段によって, 重合温度に より変わると考えられている。

最近，核磁気共鳴を利用してポリメチルメタクリレート（以下 PMMA と記す）の立体規則性の詳細を解析することが行なわれ

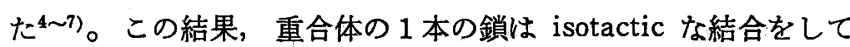
いる部分（以下 I 部分と記す）と syndiotactic の結 合になって いる部分（以下S 部分之記す）と，このいずれにす属さない結合 をしている部分 (この部分は heterotatic4) あるいは ditactic $\left.{ }^{7}\right)$ と呼ばれているのでD部分と記す）とからなり立っていると考兄 られ，これら三うの部分の割合（以下それそ゚れ $S \% ， I \%$ およ び $D \%$ と記す）が定量出来ることがわかった。

一方, PMMA の赤外線スペクトルの吸光度比 $D_{1088} / D_{1398}$ から syndiotactic 構造の割合を采，同じく $D_{749} / D_{757}$ から isotactic 構造の割合包を求める方法が別々に提出された。ところがこれら 二方法で使用している isotactic PMMA と syndiotactic PMMA との標準試料は，これらの核磁気共鳴スペクトルを測定した結

* 日本電信電話公社電気通信研究所 $:$ 東京都武藏野市吉祥寺.

1) J. W. L. Fohdham, P. H. Burleigh, C. L. Strum, J. Polymer Sci. 41, 73 (1959).

2) 今井, 前田, 浮田, 松本, 高分子化学 16, 446 (1959).

3) T.G. Fox, W.E. Goode, S. Gratch, C. M. Huggett, J. F. Kincaid, A. Spell, J.D. Stroupe. J. Polymer Sci. 31, 173 (1958).

4) F. A. Bovey, G. V. D. Tiers, J. Polymer Sci. 44, 173 (1960).

5) U. Johnson, K. Tessmar, Kolloid Z. 168, 160 (1960).

6) A. Nishioka, H. Watanabe, I. Yamaguchí and H. Shimizu, J! Polymer Sci. 45, 232 (1960).

7) 渡辺, 阿部, 園, 西岡, 国際高分子化学会議, モスクワ, 6 月 (1960).

8) U. Baimann, H. Schreiber, K. Tessmar, Makromol. Chem. 36, 81 (1960).

9）阿部，渡辺，園，高分子講演会，神戸，6月 (1960).
果, 前者はほとんど $100 \%$ [ 部分から成り立つと考えられた が，後者は $\mathrm{S}$ 部分のみよりは構成されていないことがわかった。

したがって，著者は syndiotactic の標準試料が S部分のみの 重合体でないことを考虑して, 赤外線スペクトルの吸光度比と核 磁気共鳴スペクトルより求めた $S \%$ と I\% との関連性を求める ことを試みた。また，このような手段でラジカル触媒で乳化重合 と塊状重合により得られた PMMA の S\%，I\% および D\%を 求め, その重合温度㨟よび重合率依存性を検討した。

\section{2 実験}

重合はいずれも硬質ガラス製重合管を使用し, $100^{\circ} \mathrm{C}$ 以下は回 転重合水槽で, これ以上の温度では油恒温槽で静止してそれぞれ 重合を行なった。塊状重合, 乳化重合とも一定時間後開管しメタ ノールで沈殿させた。前者はメタノールで, 後者は水, メタノー ルの順に洗浄して乾燥した。な㨋状重合の重合率の高いるのは 室温でアセトンに溶かし，メタノールで再沈殿した。

赤外線スペクトル測定用薄膜は試料約 $0.03 \mathrm{~g}$ を試験管にとり, ベンゼン $1 \mathrm{cc}$ を加えて溶かした後，ガラス板上に $5 \times 4 \mathrm{~cm}^{2}$ の 広さに流してつくった。

\section{3 重合結果および考察}

\section{1 重合体中の $S \%, I \%$ および $D \%$ の求め方}

重合体中の syndiotactic 構造の割合を求める Baumann の方

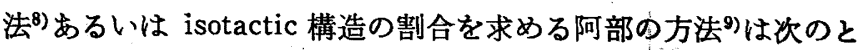
おりである。まず isotactic PMMA と syndiotactic PMMA と の標準試料を種々の割合に混合し，この混合物の赤外線スペクト ルを測定し, 混合物中の syndiotactic PMMA の量と $D_{1063} / D_{1993}$ あるいは isotactic PMMA の量と $D_{\text {749 }} / D_{757}$ との関係を予め知 り, 次に任意の重合体の $D_{1063} / D_{1993}$ あるいは $D_{749} / D_{757}$ の值か ら逆にそれぞれ syndiotactic 構造の割合あるいは isotactic 構造 の割合を求めるものである。

著者は isotactic PMMA の標準試料としてフェニルマグネシ

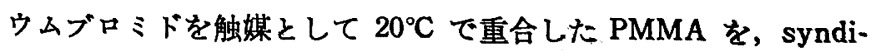

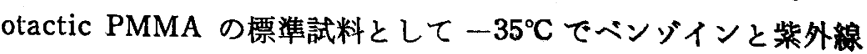


によってトルェン溶液中で重合した PMMA をそれぞれ選しだ。 前者は赤外線スペクトルお゙よび3\%クロロホルム溶液の核磁気共 鳴スペクトルの結果より $100 \%$ のI部分よりなる重合体と考兄 ても差支えないと思われる。一方後者は同様核磁気共鳴スペク トルの結果より $85 \%$ のS部分と $1.6 \%$ の I 部分と $13.4 \%$ のD 部分よりなる重合体であった。したがってこの 2 種の標準試料の 前者を $A \mathrm{~g}$ ，後者を $B \mathrm{~g}$ の割合で混合した混合物中の $S \%$ と $I \%$ はそれぞれ $S=0.85 B \times 100 /(A+B), \quad I=(0.016 B+A) /$ $(A+) B \times 100$ の各式で表わされる。

次混合物の膜の赤外線スペクトルから $D_{1068} / D_{1998}$ と $D_{749} /$ $D_{757}$ を計算し，上記の $S \%$ と、 $D_{1088} / D_{1998}$ 拉よび $I \%$ と $D_{749} /$ $D_{757}$ の関連性を図 1亿それ枈れ示した。

この syndiotactic PMMA の標準試料の実際のS\% の値は赤 外線スペクトルからは求められない。すしこの試料を $100 \%$ と仮 定すると，更に低温で重合した PMMA は $D_{1063} / D_{1993}$ が標準試 料の $D_{1008} / D_{1998}$ よりる大きくなり $S \%$ が $100 \%$ 以上になる。 更にある試料の $S \%$ を求めるとさにこの試料の実際の值との誤 差が大きくなる。したがって, 標準試料の $S \%$ と I\% とを核磁 気共鳴スペクトルより求めて図 1 をつくり, 任意の試料の赤外線 スペクトルより $D_{1068} / D_{1999}$ と $D_{749} / D_{757}$ とを計算し, これらの吸 光度比と図 1 よりその試料の $S \%$ と $I \%$ とを求めた。をた $D \%$ は赤外線スペクトル上り直接求め得なかったので，100\%ー(S\% $+I \%)$ として算出した。このようにして図 1 を利用し赤外線 ス ペクトルより求めた $S \%$ ，I\% 括よび $D \%$ の值と，溶液の核磁 気共鳴スペクトルより直接求めた值との比較は，トルエン溶液重 合した試料について後で報告する。

\section{$3 \cdot 2$ 塊状重合の重合率による立体規則性の変化}

重合時間を変えることによって異なった重合率の重合体を得 た。この重合結果と重合体の $D_{1068} / D_{1998}$ と $D_{749} / D_{767}$ の値を表 1 火示した。この表の $D_{1068} / D_{1893}$ 战よび $D_{749} / D_{767}$ の值と図 1 より重合体中の $S \%$ ，I\% および $D \%$ を求め，重合率に対する 依存性を図 2 と示した。また重合時間一重合率の関係を図 2 の点 線で示した。

重合率は 20\% 以内では重合時間に対して1次僧加して拉り, この範囲の重合率では，重合体の $S \% ， I \%$ および D\%はそれ ぞれ重合率によらず一定とい光る。しかし，重合率が重合時間に 対して急激炕㫒するゲル効果の現れるころから，重合体の $S \%$, I\% および D\% はいずれる変化する。すなわち $\mathrm{S} \%$ は減少し, $I \%$ と D\% とは增加する。。しかし，重合の末期になると S\%は

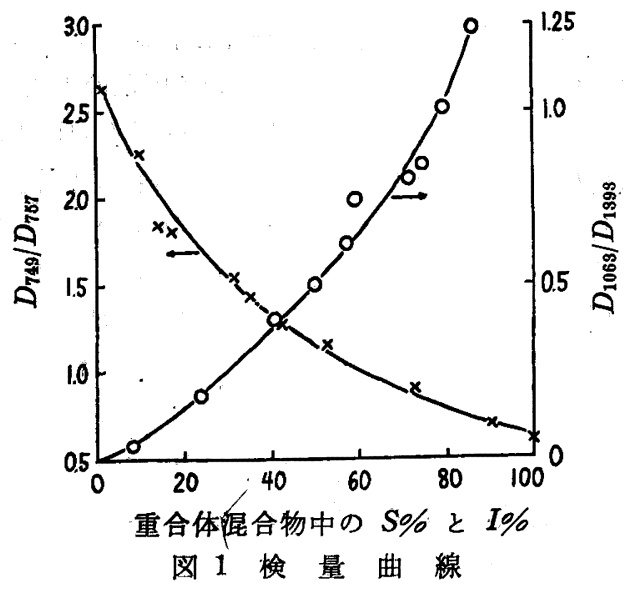

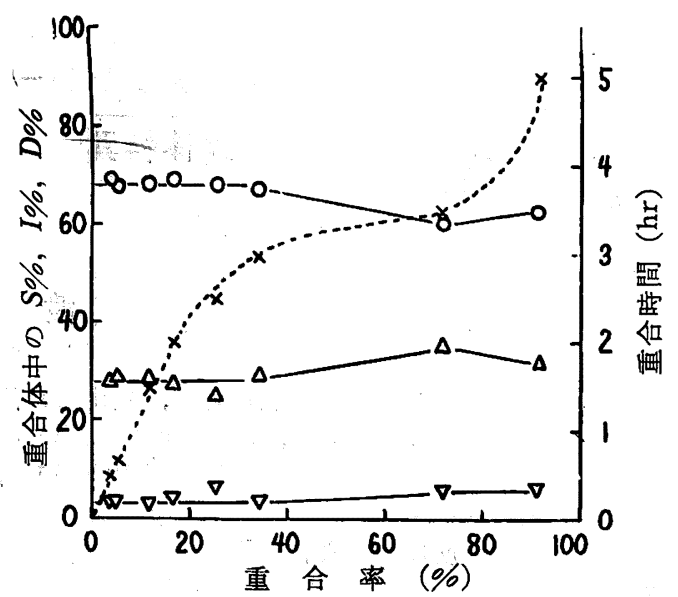

図 2 塊状重合の重合率による $S \%, I \%$ 扎よび $D \%$ の変化

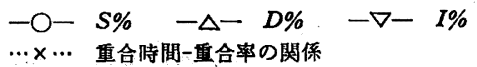

表 1 塊状重合の重合率による $D_{1063} / D_{1993}$ と $D_{749} / D_{767}$ の值

\begin{tabular}{|c|c|c|c|}
\hline $\begin{array}{l}\text { 重合封閔 } \\
\text { (min) }\end{array}$ & $\begin{array}{l}\text { 重畣率 } \\
\end{array}$ & $D_{1089} / D_{1393}$ & $D_{718} D_{757}$ \\
\hline 30 & 3. 96 & 0.805 & 2.24 \\
\hline 40 & 5.24 & 0.785 & 2.23 \\
\hline 90 & 12.05 & 0.796 & 2. 28 \\
\hline 120 & 16.75 & 0.808 & 2.21 \\
\hline 150 & 25.50 & 0.800 & 2.19 \\
\hline 180 & 34.21 & 0.783 & 2.27 \\
\hline 210 & 71.45 & 0.670 & 2.13 \\
\hline 300 & 91.15 & 0.706 & 2.13 \\
\hline 360 & 92.74 & 0.714 & 2.03 \\
\hline
\end{tabular}

B.P.O. $0.05 \mathrm{~g}$, MMA $10 \mathrm{cc}$ ，重合温度 $60^{\circ} \mathrm{C}$

表 2 塊状重合の重合温度による重合結果

\begin{tabular}{|c|c|c|c|c|c|}
\hline B.P.O. & $\begin{array}{l}\text { 重合温度 } \\
\left.{ }^{\circ} \mathrm{C}\right)\end{array}$ & $\begin{array}{c}\text { 重合洔間 } \\
(\min )\end{array}$ & $\begin{array}{l}\text { 重合率 } \\
\text { (\%) }\end{array}$ & $D_{1083} / D_{1393}$ & $D_{748} D / 757$ \\
\hline 0.05 & 30 & 247 & 7.52 & 0.855 & 2.36 \\
\hline " & 40 & 162 & 11.59 & 0.820 & 2.35 \\
\hline "I & 50 & 122 & 14.29 & 0.809 & 2.21 \\
\hline " & 60 & 68 & 20.68 & 0.780 & 2.20 \\
\hline "I & 70 & 30 & 15.09 & 0.746 & 2.12 \\
\hline 0 & 100 & 126 & 2.11 & 0.695 & 2.14 \\
\hline$"$ & 120 & 60 & 6.80 & 0.641 & 2.05 \\
\hline " & 140 & 35 & 7.04 & 0.621 & 2.03 \\
\hline
\end{tabular}

若干增加する傾向を示す。重合温度が $60^{\circ} \mathrm{C}$ 以外の場合飞も，ゲ ル効果が現われる重合率に抏いて重合体の立体規則性は重合率に よって影響を受け， $60^{\circ} \mathrm{C}$ の場合と同様に S\% が少なくなり I\% とD\%が多くなると考えられる。

3.3 塊状重合の重合温度による立体規則性の变化

ゲル効果が現われる前では重合体の立体規則性は重合率によっ て変わらないと見なされる。したがゥてゲル効果が現われる前で

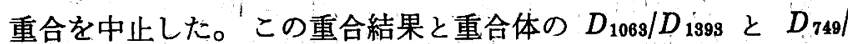
$D_{757}$ の値とを表 2 亿示した。また前と同様にして重合体の $S \%$, $I \%$ 执よび D\%を求めこれらの重合温度依存性を図 3 に示した。

Bovey と Tiers') はラジカル重合によって得られた PMMA の $S \%, I \%$ 㧊よび D\% は一つのパラメーター゙によって次の ように表わされることを示した。

$$
S / 100=\beta^{2}, \quad I / 100=(1-\beta)^{2}, \quad D / 100=2 \beta(1-\beta)
$$
ここでパラメーター $\beta$ は単量体が syndiotactic 飞付加する確率 である。これらの関係を四示すると因 4 の 3 本の曲線として表わ される。したがって，S/100 は曲線 1 の上淿あり，I/100 は曲線 3 の上にあり，また $D / 100$ は曲線 2 の上にある。 


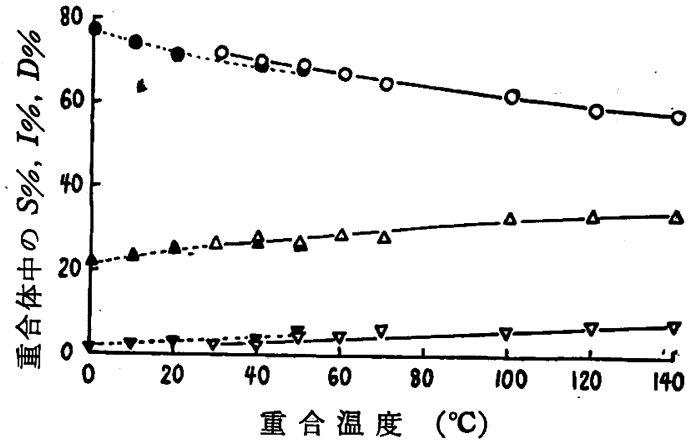

因 3 重合温度によるS\%，I\% および D\%の変化

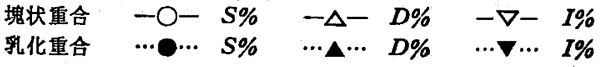

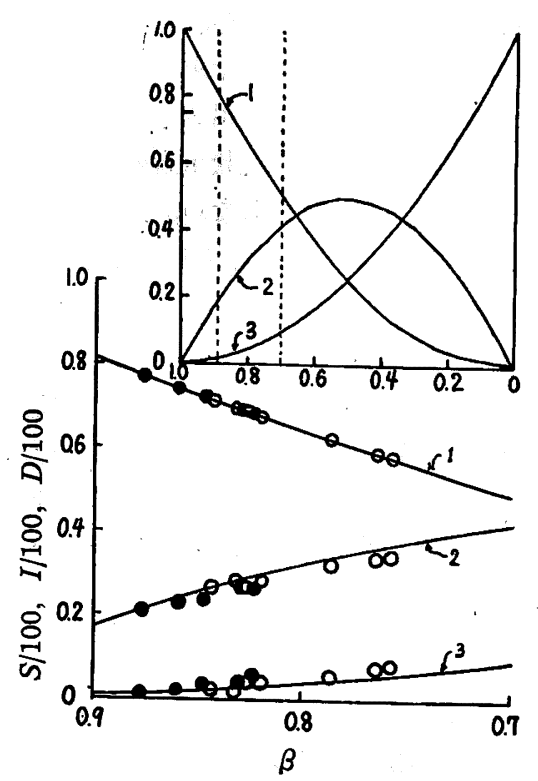

因 $4 \beta$ と $S / 100, I / 100$ および $D / 100$ との関係

$1: S / 100,2: D / 100,3: I / 100$

上の四は $\beta$ が 0から 1.0 までの全域にわたる

そ $S / 100, I / 100, D / 100$ の関保を示したすのて あり,下の四は上の四の点線内を脚赃大したも

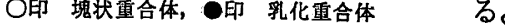

$$
\beta=\sqrt{S / 100}, \quad 1-\beta=1-\sqrt{S / 100}
$$

また $\beta$ と $(1-\beta)$ との比は次の式で表わされる10)。

$$
\frac{\beta}{1-\beta}=A e^{-\left(E_{\mathrm{s}}-E_{\mathrm{i}}\right) / R T}
$$

ここで $A$ は一定， $E_{\mathrm{s}}$ および $E_{1}$ はそれぞれ syndiotactic およ び isotacticに付加する活性化エネルギーである。また（2）式 を（3）式に代入して常用対数に直すと,

$$
\log \sqrt{\frac{S}{100}}-\log \left(1-\sqrt{\frac{S}{100}}\right)=\log A-\frac{E_{\mathrm{s}}-E_{1}}{4.61} \times \frac{1}{T}
$$

（4）式を使用して，重合体の $S \%$ と $1 / T$ との関係を図示する と図 5 となる。この図より塊状重合の場合の $-\left(E_{\mathrm{s}}-E_{\mathrm{i}}\right)$ を求め ると $1.38 \mathrm{kcal}$ となる。

この值を（4）式に代入し； $\log A$ を計算し整理すると次の式 を得る。

$$
\begin{aligned}
\log \sqrt{\frac{S}{100}} & -\log \left(1-\sqrt{\frac{S}{100}}\right) \\
= & -0.26+0.30 \times 10^{8} \times 1 / T
\end{aligned}
$$

10) J.W.L. Fohdham, J. Polymer Sci. 39, 321 (1959).

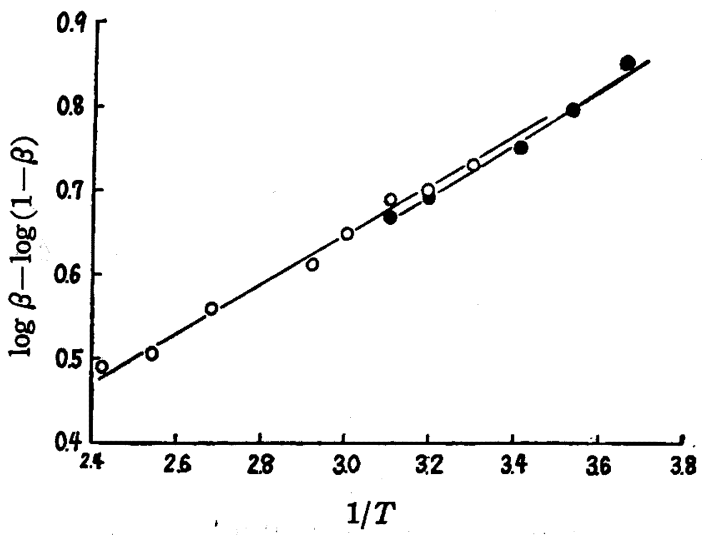

圀 $5 \log \beta-\log (1-\beta)$ そ $1 / T$ との関係 -O- 塊状重合 -0 - 䄻化重合

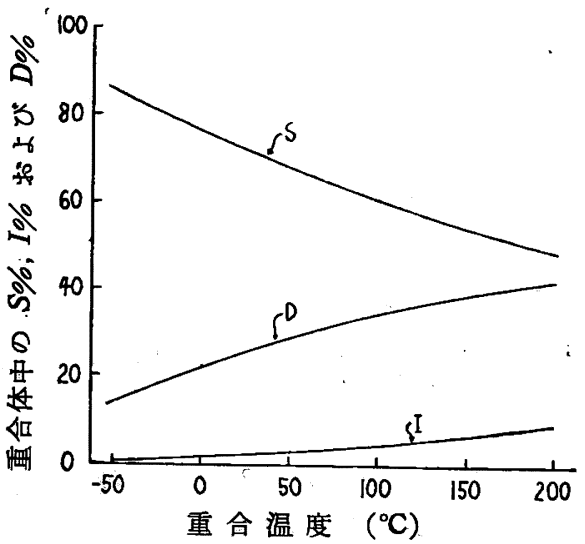

図 6 実験式より求めた塊状重合に打ける重合温度と $S \%, I \%$ および $D \%$ 々の関係

（5）式は塊状重合した場合の重合温度と重合体中の S\% との間 の実験式である。この関係を図示すると図 6 の曲線 $S$ となる。 また S\% が決まれば，（1）式よりI\%とD\%とが算出される ので, 重合温度と I\% および $D \%$ との関係も図6の曲線 $I$ お よび $D$ のように図示される。

この図より，任意の重合温度で得られた重合体の $S \% ， I \%$ お よび $D \%$ をそれぞれ求めることができる。逆にある $S \%$ の重合 体を得るには重合温度を何度にして重合すればよいかがわかる。 たとえば $90^{\circ} \mathrm{C}$ での重合体の立体構造は $S=62 \% ， I=4 \%$ および $D=34 \%$ の各成分よりなり，逆に $S=80 \%$ の重合体を得るには

\begin{tabular}{|c|c|c|c|c|}
\hline $\begin{array}{l}\text { 電合温度 } \\
\left({ }^{\circ} \mathbf{C}\right)\end{array}$ & $\begin{array}{l}\text { 重合洔間 } \\
\text { (min) }\end{array}$ & 重含) & $D_{1083} / D_{1303}$ & $D_{749} D_{757}$ \\
\hline 0 & 540 & 71.64 & 0.964 & 2.57 \\
\hline$" 1$ & 362 & 4.66 & 1.000 & 2.43 \\
\hline 10 & 219 & 77.97 & 0.907 & 2.30 \\
\hline " & 80 & 8.82 & 0.923 & 2.45 \\
\hline 20 & 110 & 98.64 & 0.851 & 2.30 \\
\hline " & 35 & 16.20 & 0.873 & 2.23 \\
\hline 40 & 49 & 98.07 & 0.814 & 2.38 \\
\hline$"$ & 35 & 83.49 & 0.809 & 2.27 \\
\hline " & 22 & 29.70 & 0.820 & 2.24 \\
\hline "I & 11 & 0.76 & 0.834 & 2.26 \\
\hline 50 & 14 & 97.66 & 0.782 & 2.14 \\
\hline " & 9 & 76.03 & 0.796 & 2.10 \\
\hline " & 35 & 98.83 & 0.790 & 2.23 \\
\hline$"$ & 5 & 13.78 & 0.791 & 2.13 \\
\hline
\end{tabular}
$-20^{\circ} \mathrm{C}$ で重合すればよいことになる。

3.4 乳化重合体の立体規則性の重合率および重合温度依存性 $0^{\circ} \mathrm{C}$ より $50^{\circ} \mathrm{C}$ までの重合温度範囲内の重合結果と重合体の

表 3 乳化重合の重合結果

K.P.S. $0.10 \mathrm{~g}, \mathrm{NaHSO}_{3} 0.025 \mathrm{~g}, 0.5 \%$ モノゲン水流液 $20 \mathrm{cc}, \mathrm{MMA} 10 \mathrm{cc}$ 
$D_{1063} / D_{1999}$ および $D_{749} / D_{757}$ の值とを表 3 に示した。この表より， 各重合温度での低重合率と高重合率の重合体の各吸光度比の値は ほとんど同じであり，塊状重合の場合のよ゙5に S\%,I\%および D\% は重合率によって大きな変化を受けないことがわかる。

重合温度を变えて得られた重合体の $S \%$ と I\% とを求め, 更 に $D \%$ を計算し，これら三つの值の重合温度依存性を図 3 に示 した。釈化重合の場合にも重合温度が上䄯すると，S\% が减少し $I \%$ と $D \%$ とは増加する。ここで塊状重合と乳化重合との重合 体の $\mathrm{S} \%$ ，I\% および $D \%$ を各温度について比較すると，ほと んど同じ値である。したがって，塊状重合と乳化重合において， 乳化重合によって特に立体規則性が異なる重合体は得られない。 釈化重合体の $S / 100, I / 100$ および $D / 100$ の值が(1) 式を満 足しているかを確めるため流，これらの值を図 4 に入れた。大体 各々の曲線の上にあると考えられる。したがって，乳化重合によ って得られた重合体の立体規則性は（1）式を満足しながら, 重 合温度が上年すると S\% が減少する方向に変化する。

前と同様に $\beta$ を計算し, $\log \beta-\log (1-\beta)$ と $1 / T$ との関係を 図 5 に示した。またこの図より乳化重合の場合の $-\left(E_{\mathrm{g}}-E_{1}\right)$ の 値は $1.44 \mathrm{kcal}$ である。この值を（4）式に代入し $S \%$ と $1 / T$ との実験式を求めると（6）式のようになる。

$$
\log \sqrt{\frac{S}{100}}-\log \left(1-\sqrt{\frac{S}{100}}\right)=-0.30+0.31 \times 10^{3} \times \frac{1}{T}
$$

この式より $S \%$ と重合温度との関係を図示すると図 7 の曲線 $S$ になり, 更に $I \%$ および $D \%$ と重合温度との関係を示すと曲線 $I$ と $D$ Kなる。したがってこの図を使用すると乳化重合に和け る重合温度と $S \%$, I \% 拉よび $D \%$ の関係を求め得る。

\section{4 結語}

syndioactic と isotactic PMMA の標準試料の $S \%, I \%$ およ び D\%をクロロホルム溶液の核磁気共鳴スペクトルより求め, こ扎らの值を採用して，赤外線スペクトルにより $S \% ， I \%$ 扰よ

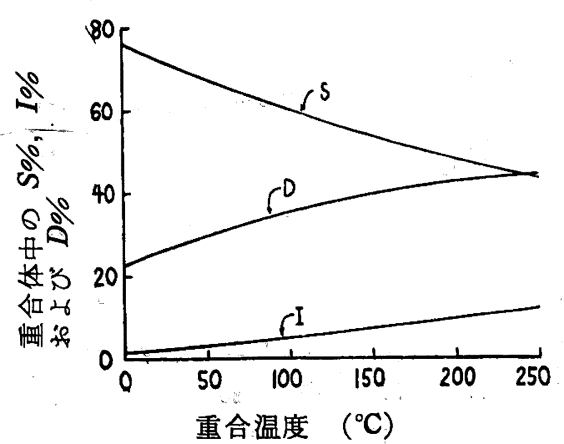

図 7 実験式より求めた乳化重合に打ける重合温度 と $S \% ， I \%$ 扰よび $D \%$ との関係

び $D \%$ を求めることを試みた。

この方法によりラジカル触媒で塊状重合法および乳化重合法に よって得られた重合体の S\%，I\%および D\%を求めると，こ れらの相互の間汇は Bovey と Tiersによって提出された式をほ ほ満足することがわかった。またこれらの值は塊状重合の場合は 重合率によって異なるが乳化重合の場合は変化しない。更に重合 温度が上界すると，両重合方法による場合ともS\%が減少し I\% と D\% とは增加する。

重合温度の逆数とS\% との間の実験式を求め, この式を使用 して S\% と重合温度との関係をかなり広い温度範囲にわたって 図示した。乳化重合と塊状重合を比較すると, 各重合温度に拈い てほとんど同じ $S \%, I \%$ 拉よ゙ $D \%$ を示す。このことは二つ の重合機構に本質的な差異がないといら一つの証拠を提供してい る。

本研究を行ならに当り，御指導頂きました西岡篤夫室長，核磁 気共鳴スペクトルょり標準陚料の $S \%$ ，I\% および $D \%$ を求め て頂いた当研究所の加藤氏, 実験に協力して頂いた園靖之助氏に 感謝致します。 